\title{
REKAYASA PERANGKAT LUNAK GUNA MENENTUKAN PENYAKIT TANAMAN PADI DENGAN METODE FUZZY MAMDANI
}

\author{
Muhamad Abor ${ }^{1}$ Pitrawati ${ }^{2}$ \\ STMIK Dian Cipta Cendikia, Kota Bumi ${ }^{1}$ \\ AMIK Dian Cipta Cendikia, Bandar Lampung ${ }^{2}$ \\ E-mail : muhamadabror78@gmail.com,pitrawati@dcc.ac.id
}

\begin{abstract}
ABSTRAK
Indonesia merupakan salah satu negara yang memiliki penduduk dengan mata pencarian bertani atau bercocok tanam. Salah satu hasil pertanian yang utama adalah padi. Padi merupakan kebutuhan pokok masyarakat Indonesia, sehingga pemerintah berkewajiban untuk menjaga stabilitas pangan dengan menjaga ketersedian padi. Salah satu faktor yang menyebabkan terganggunya stabilitas ketersedian padi di petani adalah penyakit tanaman padi. Kurangnya informasi pengendalian penyakit dan terbatasnya pakar menyebabkan permasalahan tersebut belum dapat diatasi secara maksimal.
\end{abstract}

Penelitian ini bertujuan untuk mengembangkan rekayasa perangkat lunak guna menentukan penyakit tanaman padi dengan menggunakan metode Fuzzy Mamdani. Metode pengembangan sistem yang digunakan adalah extreme programming. Alat pengembangan sistem menggunakan Unified Modeling Language dengan alat rancangan berupa Usecase, Activity Diagram dan Class Diagram. Metode penalaran yang digunakan adalah fuzzy mamdani.

Penelitian ini menghasilkan Aplikasi yang dapat menentukan penyakit tanaman padi dengan mengidentifikasi 6 jenis penyakit dengan 22 gejala. Pengujian yang lakukan menunjukan bahwa aplikasi telah berhasil dijalankan sesuai dengan setiap kelas uji dan daftar pengujian yang diberikan.

Kata kunci : Rekayasa Perangkat Lunak, Penyakit Tanaman Padi, Fuzzy Mamdani

\section{ABSTRACT}

Indonesia is one of the countries that have a population with a livelihood as farmer or farming. One of the main agricultural products is rice. Rice is the basic needs of Indonesian people, so the government is obliged to guarantee the availability of food with availability rice. One of the factors causing the disruption of rice availability in farmer is the rice plant disease. Lack of information on handling the disease and the limited strategy causes the problem can not be solved optimally.

This study discusses the development of software to overcome the rice plant diseases using Fuzzy Mamdani method. The system development method used is extreme programming. System development tools use Unified Modeling Language with design tools consisting of Usecase, Activity Diagram and Class Diagram. The reasoning method which used is fuzzy mamdani.

This research produces an application which can overcome the rice plant disease by identifying 6 types of diseases with 22 symptom. The test which is carried out shows that the application has been successfully run in accordance with each test class and the list of provided tests

Keywords: Software Engineering, The Rice Plant Disease, Fuzzy Mamdani Method

\section{PENDAHULUAN}

Rekayasa perangkat lunak merupakan proses pengembangan aplikasi. Aplikasi merupakan sekumpulan atribut yang terdiri dari beberapa form, report yang disusun sedemikian rupa sehingga dapat mengakses data. aplikasi secara umum adalah suatu proses dari cara manual yang ditransformasikan ke komputer dengan membuat sistem atau program agar data diolah lebih berdaya guna secara optimal.

Aplikasi penentuan penyakit padi merupakan media yang digunakan dalam mendeteksi 
panyakti padi yaitu meliputi nama penyakit, jenis penyakit dan diagnosanya serta alat sarana bagi petani untuk pengetahui sumber pennyakit padi, jika aplikasi penentuan penyakit padi itu didesain dan dikembangkan secara baik, maka fungsi itu akan dapat diperankan oleh media meskipun tanpa keberadaan dari ahli petani, secara umum manfaat apliksi penentuan penyakit padi adalah memperlancar interaksi antara petani lokal dengan ahli petani sehingga kegiatan untuk mengetahui penyakit padi akan lebih efektif.

Sistem tersebut berfungsi untuk mempermudah perluasan untuk mengetahui jenis penyakit kepada masyarakat ini, Sistem ini juga diharapkan dapat memberikan informasi yang baik untuk petani maupun pengguna mengetahui penyakit-penyakit pada tanaman padi besertta gejala dan pengendaliannya

Dengan aplikasi penentuan penyakit pada tanaman padi dengan menggunakan metode fuzzy mamdani diharapkan akan membantu masyarakat luas terutama para petani yang tanaman padinya sedang terserang penyakit agar mengetahui cara membasmi penyakit pada padi tersebut sehingga tidak mengalami gagal panen

\subsection{Rumusan Masalah}

Berdasarkan latar belakang masalah, maka yang akan menjadi pembahasan dalam identifikasi masalah adalah :

1. Kurangnya pemahaman petani dalam mengatasi penyakit tanaman padi

2. Sulitnya para petani dalam mencari informasi mengenai penyakit tanaman padi

1.3 Batasan Masalah

Ruang Lingkup masalah pada penelitian ini adalah :

1. Aplikasi ini mendiagnosa 6 penyakit pada tanaman padi.

2. Aplikasi ini menggunakan 22 gejala penyakit

3. Aplikasi menggunakan metode fuzzy mamdani.

\subsection{Rumusan Penelitian}

Rumusan masalah pada penelitian ini adalah Bagaimana Rekayasa perangkat lunak guna menentukan penyakit tanaman padi dengan metode Fuzzy Mamdani ?

1.5 Tujuan dan Manfaat Penelitian

Kegunaan dari penelitian adalah sebagai berikut :
1. Membantu masyarakat mendapatkan informasi tentang jenis-jenis penyakit padi

2. Mempermudah masyarakat untuk mengetahui jenis penyakit pada padi

3. Mempermudah masyarakat untuk mendiagnosa penyakit pada padi

\section{METODE PENELITIAN}

2.1 Metode Penelitian

Jenis penelitian yang digunakan adalah deskriptif. Penelitian deskriptif adalah survei, metode survei merupakan penyelidikan yang diadakan untuk memperoleh fakta-fakta dari gejala-gejala yang ada dan mencari keteranganketerangan secara faktual baik tentang institusi sosial, ekonomi, atau politik dari suatu kelompok maupun suatu daerah (Nazir, 2014).

Metode pengembangan perangka lunak dengan menggunakan Extreme Programming (XP). Extreme Programming (XP) merupakan suatu pendekatan yang paling banyak digunakan untuk pengembangan perangkat lunak cepat.

Landasan penggunakan metode Extreme Programming (XP) karena sifat dari aplikasi yang dikembangkan dengan cepat melalui tahapan- tahapan yang ada meliputi : planning design, coding dan testing.

\subsection{Teknik Pengumpulan Data}

Dalam penelitian ini teknik pengumpulan data menggunakan beberapa metode antara lain adalah :

1. Metode Wawancara

2. Metode Observasi

3. Metode Kepustakaan

2.3 Alat Pengembangan Sistem

"Unified Modeling Language (UML) adalah Metodologi kolaborasi antara metoda-metoda Booch, OMT (Object Modeling Technique), serta OOSE (object Oriented Software Enggineering) dan beberapa metoda lainnya, merupakan metodologi yang paling sering digunakan saat ini untuk analisa dan perancangan sistem dengan metodologi berorientasi objek mengadaptasi maraknya penggunaan bahasa "pemrograman berorientasi objek" (OOP)".

UML merupakan bahasa standar untuk penulisan blueprint software yang digunakan untuk visualisasi, spesifikasi, pembentukan dan pendokumentasian alat-alat dari sistem perangkat lunak. 
2.3.1 Use Case Diagram

Menurut Rosa dan Shalahuddin, (2014) mengemukakan :

Use Case Diagram merupakan pemodelan untuk melakukan (behavior) sistem informai yang akan dibuat. Use case digunakan untuk mengetahui fungsi apa saja yang ada di dalam sebuah sistem informasi dan siapa saja yang berhak menggunakan fungsi-fungsi itu. Berikut adalah simbol-simbol yang ada pada diagram use case.

Tabel 1. Simbol Use Case

\begin{tabular}{|c|c|c|c|}
\hline No & $\begin{array}{c}\text { Notas } \\
\text { i }\end{array}$ & Keterangan & Simbol \\
\hline 1 & Actor & $\begin{array}{l}\text { Pengguna } \\
\text { sistem atau } \\
\text { yang } \\
\text { berinteraksi } \\
\text { langsung } \\
\text { dengan } \\
\text { sistem }\end{array}$ & \\
\hline 2 & $\begin{array}{l}\text { Use } \\
\text { Case }\end{array}$ & $\begin{array}{l}\text { Lingkaran } \\
\text { elips dengan } \\
\text { nama } u s e \\
\text { case nya } \\
\text { tertulis } \\
\text { ditengah } \\
\text { lingkaran }\end{array}$ & ase \\
\hline 3 & $\begin{array}{l}\text { Assoc } \\
\text { ation }\end{array}$ & $\begin{array}{l}\text { Garis yang } \\
\text { berfungsi } \\
\text { menghubung } \\
\text { kan actor } \\
\text { dengan use } \\
\text { case. }\end{array}$ & \\
\hline 4 & $\begin{array}{l}\text { Relas } \\
i\end{array}$ & $\begin{array}{l}\text { Sebagai } \\
\text { penghubung } \\
\text { antara actor } \\
\text { usecase, use } \\
\text { case-usecase } \\
\text { dll }\end{array}$ & \\
\hline 5 & $\begin{array}{l}\text { Inclu } \\
\text { de } \\
\text { Relati } \\
\text { onshi } \\
p\end{array}$ & $\begin{array}{l}\text { Memungkin } \\
\text { kan suatu } \\
\text { usecase } \\
\text { untuk } \\
\text { menggunaka } \\
\text { n } \\
\text { fungsionalita } \\
\text { s yang } \\
\text { disediakan } \\
\text { oleh usecase } \\
\text { yang } \\
\text { lainnya. }\end{array}$ & $<$ include $>>$ \\
\hline
\end{tabular}

\begin{tabular}{|c|c|c|c|}
\hline 6 & $\begin{array}{l}\text { Exten } \\
d \\
\text { Relati } \\
\text { onshi } \\
p\end{array}$ & $\begin{array}{l}\text { Memungkin } \\
\text { kan usecase } \\
\text { memiliki } \\
\text { kemungkina } \\
\mathrm{n} \text { untuk } \\
\text { memperluas } \\
\text { fungsionalita } \\
\text { s yang } \\
\text { disediakan } \\
\text { oleh usecase } \\
\text { yang } \\
\text { lainnya. }\end{array}$ & $<$ extend $>>$ \\
\hline
\end{tabular}

2.3.2 Activity Diagram

Menurut Rosa dan Shalahuddin, (2014) mengemukakan :

Activity Diagram menggambarkan workflow (aliran kerja) atau aktivitas dari sebuah sistem atau proses bisnis atau menu yang ada pada perangkat lunak. Perlu diperhatikan bahwa diagram aktivitas menggambarkan aktivitas sistem bukan apa yang dilakukan aktor, jadi aktivitas yang dapat dilakukan oleh sistem. Berikut adalah simbol-simbol yang ada pada diagram aktivitas.

Tabel 2. Simbol Activity Diagram

\begin{tabular}{|c|l|l|l|}
\hline No & Notasi & Keterangan & Simbol \\
\hline 1 & $\begin{array}{l}\text { Initial } \\
\text { State }\end{array}$ & $\begin{array}{l}\text { Titik awal } \\
\text { untuk } \\
\text { memulai } \\
\text { suatu } \\
\text { aktivitas }\end{array}$ & $\begin{array}{l}\text { Titik akhir } \\
\text { untuk } \\
\text { mengakhiri } \\
\text { suatu } \\
\text { aktivitas }\end{array}$ \\
\hline 3 & $\begin{array}{l}\text { Final } \\
\text { State }\end{array}$ & $\begin{array}{l}\text { Menandakan } \\
\text { sebuah } \\
\text { aktivitas }\end{array}$ & \\
\hline 4 & $\begin{array}{c}\text { Activity } \\
\text { teciSis }\end{array}$ & $\begin{array}{l}\text { Pilihan untuk } \\
\text { pengambilan } \\
\text { keputusan }\end{array}$ & \\
\hline 5 & $\begin{array}{c}\text { Montrol } \\
\text { Flow }\end{array}$ & $\begin{array}{l}\text { Arus } \\
\text { aktivitas }\end{array}$ \\
\hline
\end{tabular}




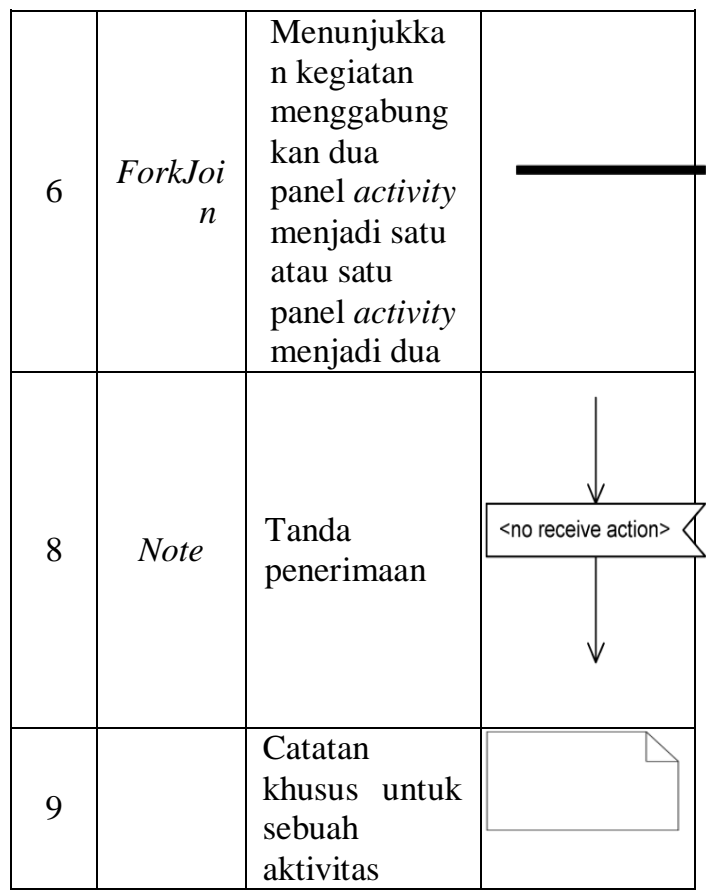

2.3.3 Class Diagram

Menurut Rosa dan Shalahuddin (2014) mengemukakan :

Class Diagram menggambarkan struktur sistem dari segi pendefinisian kelas-kelas yang akan dibuat untuk membangun sistem. Kelas memiliki apa yang disebut atribut dan metode atau operasi. Berikut adalah simbolsimbol yang ada pada diagram Kelas.

Tabel 3. Simbol Class Diagram

\begin{tabular}{|c|c|c|c|}
\hline No & Notasi & Keterangan & Simbol \\
\hline \multirow{12}{*}{1} & \multirow{12}{*}{ Object } & \multirow{12}{*}{$\begin{array}{l}\text { Blok-blok } \\
\text { pembangun } \\
\text { program. } \\
\text { Bagian atas } \\
\text { class } \\
\text { menunjukkan } \\
\text { namadari class, } \\
\text { bagian tengah } \\
\text { mengindikasika } \\
\text { n atribut dari } \\
\text { class, dan } \\
\text { bagian bawah } \\
\text { mendefinisikan } \\
\text { method dari } \\
\text { sebuah class }\end{array}$} & Class Diagram \\
\hline & & & \\
\hline & & & \\
\hline & & & \\
\hline & & & \\
\hline & & & \\
\hline & & & \\
\hline & & & \\
\hline & & & \\
\hline & & & \\
\hline & & & \\
\hline & & & \\
\hline \multirow{4}{*}{2} & \multirow{4}{*}{$\begin{array}{c}\text { Activatio } \\
n\end{array}$} & \multirow{4}{*}{$\begin{array}{l}\text { Menunjukkan } \\
\text { relationship } \\
\text { atau hubungan } \\
\text { antar class }\end{array}$} & \\
\hline & & & \\
\hline & & & \\
\hline & & & \\
\hline 3 & Lifeline & Menunjukkan & \\
\hline
\end{tabular}

\begin{tabular}{|l|l|l|}
\hline & $\begin{array}{l}\text { ketergantungan } \\
\text { antara satu class } \\
\text { dengan class } \\
\text { yang lain }\end{array}$ & \\
\hline
\end{tabular}

2.3.4 Metode Fuzzy Mamdani

Logika fuzzy adalah suatu cara yang tepat untuk memetakan suatu ruang input ke dalam suatu ruang output. Titik awal dari konsep modern mengenai ketidakpastian berasal dari paper yang dibuat oleh Lofti A Zadeh, dimana Zadeh memperkenalkan teori yang memiliki obyekobyek dari himpunan fuzzy yang memiliki batasan yang tidak presisi dan keanggotaan dalam himpunan fuzzy dan bukan dalam bentuk logika benar (true) atau salah (false), tapi dinyatakan dalam derajat (degree).

Logika fuzzy sudah banyak diterapkan di berbagai bidang, baik di dunia industri maupun bisnis. Berbagai teori di dalam perkembangan logika fuzzy dapat digunakan memodelkan berbagai sistem. Bahkan sekarang ini aplikasi logika fuzzy semakin menjamur seiring dengan pesatnya perkembangan teknoTdgiskinagułasi.

\subsection{Bahasa Pemrograman}

\subsubsection{Xampp}

XAMPP merupakan paket PHP dan $M y S Q L$ berbasis open source, yang dapat digunakan sebagai tools pembantu pengembangan aplikasi berbasis PHP. XAMPP mengkombinasikan beberapa paket perangkat lunak berbeda ke dalam satu paket.

Menurut Mulhim (2013), “XAMPP adalah paket instalasi program yang terdiri atas program Apache HTTP Server, MySQL Database, dan penerjemah bahasa yang ditulis dengan bahasa pemrograman PHP dan perl".

\subsubsection{HTML}

Menurut Sibero (2012) HTML (Hyper Text Markup Language) adalah bahasa yang digunakan pada dokumen web sebagai bahasa untuk pertukaran dokumen web.

\subsubsection{MySQL}

MySQL merupakan RDBMS (atau server database) yang mengelola database dengan cepat menampung dalam jumlah sangat besar dan dapat di akses oleh banyak user.

Menurut Arief (2011) MySQL (My Structure Query Languange) adalah salah satu jenis 
database server yang sangat terkenal dan banyak digunakan untuk membangun aplikasi web yang menggunakan database sebagai sumber dan pengelolaan datanya. Mysql bersifat open source dan menggunakan SQL (Structured Query Languange). MySQL biasa dijalankan diberbagai platform misalnya windows Linux, dan lain sebagainya.

\subsubsection{PHP}

Menurut Arief: (2011) PHP merupakan bahasa pemrograman berbasis web yang memiliki kemampuan untuk memproses data dinamis. PHP dikatakan sebagai sebuah server-side embedded script language artinya sintaks-sintaks dan perintah yang diberikan oleh penulis sepenuhnya dijalankan oleh server tetapi disertakan pada halaman HTML biasa. Aplikasiaplikasi yang dibangun oleh PHP pada umumnya akan memberikan hasil pada web browser tetapi prosesnya secara keseluruhan dijalankan di server.

\subsubsection{Apache}

Apache merupakan web server yang paling banyak dipergunakan di Internet. Program ini pertama kali didesain untuk sistem operasi lingkungan Unix. Namun demikian pada beberapa versi berikutnya Apache mengeluarkan programnya yang dapat dijalankan di Windows NT.

Saat ini Apache dipergunakan secara luas. Hal ini disebabkan karena programnya yang gratis dengan kinerja relatif stabil. Dalam pengembangannya pun mempergunakan sistem Bazaar yakni tiap orang dibuka kesempatan seluas-luasnya untuk dapat memberikan kontribusi dalam mengembangkan program. Kontribusi dikomunikasikan lewat mailing list. Tim Apache mempunyai mailing list yang terbukauntuk siapa saja yang ingin ambil bagiansehingga banyak kelebihan yang ditawarkan web server Apache.

\section{HASIL DAN PEMBAHASAN}

\subsection{Hasil Penelitian}

3.1.1 Analisa Kebutuhan Sistem

Analisa kebutuhan sistem pada penelitian ini dilakukan dengan mengumpulkan data - data melalui observasi, wawancara, studi kepustakaan dan dokumentasi yang dilakukan pada langsung survei di lingkungan masyarakat di daerah yang terdapat area pertanian yang terkena penyakit.
Berdasarkan hasil pengumpulan data maka penulis dapat mengindentifikasikan masalah yang terjadi yaitu kurangnya pemahaman petani dalam mengatasi penyakit tanaman padi dan Sulitnya para petani dalam mencari informasi mengenai penyakit tanaman padi

Kebutuhan input yang digunakan untuk mengoperasikan penerapan Informasi masyarakat petani yaitu sebagai berikut

1. Data user

2. Input data penyakit

3. Input data gejala penyakit

\subsection{Perancangan Sistem \\ 3.2.1 Use Case Diagram}

Use case diagram yaitu salah satu jenis diagram pada UML yang menggambarkan interaksi antara sistem dan aktor, use case diagram juga dapat men-deskripsikan tipe interaksi antara si pemakai sistem dengan sistemnya.

\subsubsection{Class Diagram}

\section{Gambar 2. Class Diagram}

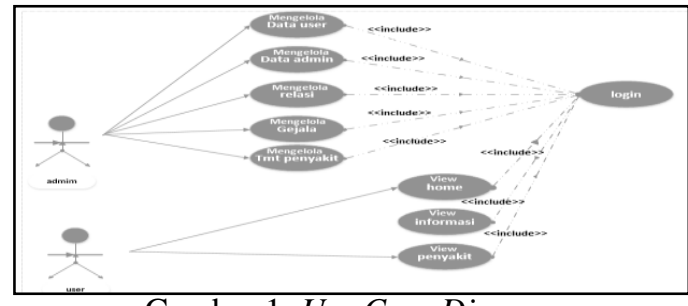

Gambar 1. Use Case Diagram

\subsubsection{Activity Diagram}

Activity Diagram ini menggambarkan rangkaian aliran dari aktivitas, digunakan untuk mendeskripsikan aktivitas yang dibentuk dalam suatu operasi sehingga dapat juga digunakan untuk aktivitas lainnya seperti use case atau

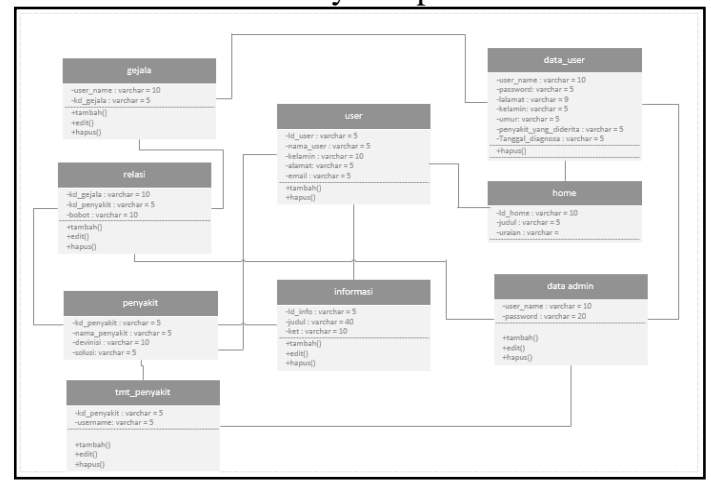

interaksi. Activity diagram dapat dilihat pada gambar di bawah ini: 


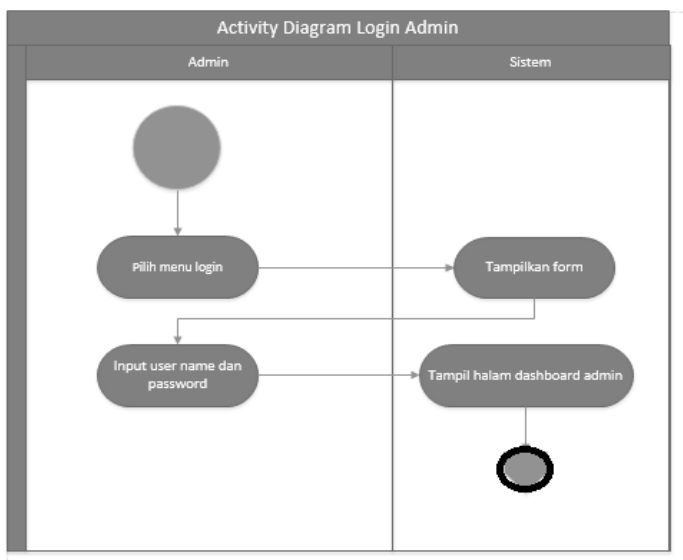

Gambar 3. Activity Diagram Login Admin

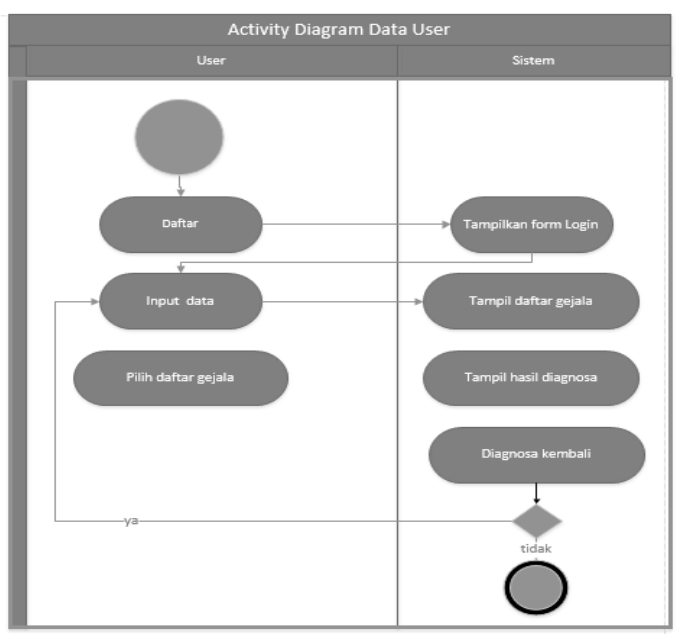

Gambar 4. Activity Diagram User

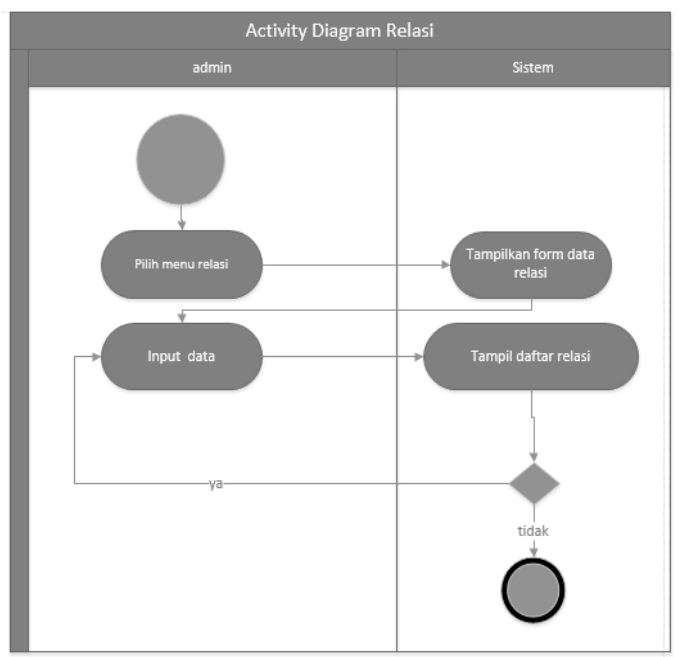

Gambar 5. Activity Diagram Relasi

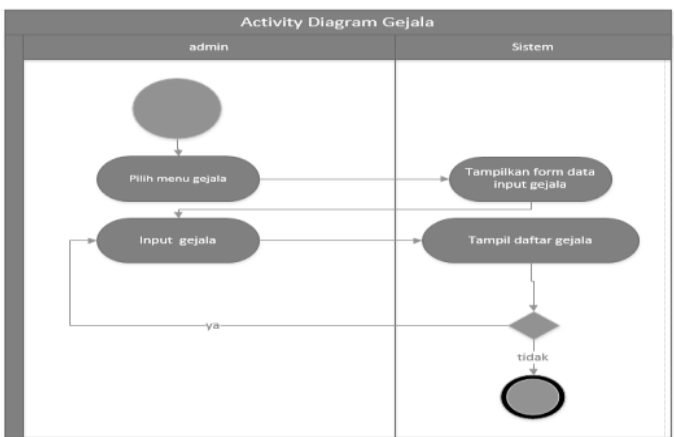

Gambar 6. Activity Diagram Gejala

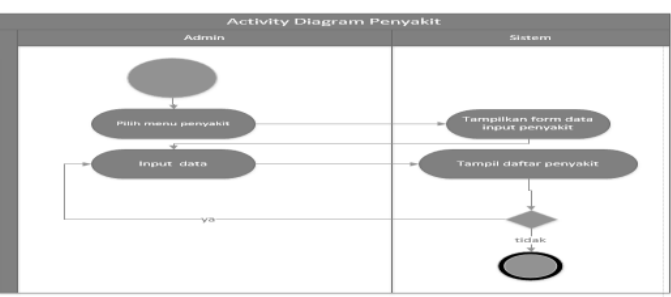

Gambar 7. Activity Diagram Penyakit

\subsubsection{Rancangan Input}

1. Rancangan Halaman Login Admin

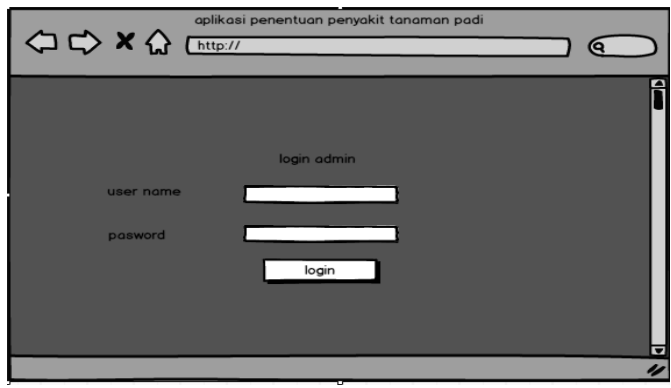

Gambar 8. Halaman Login

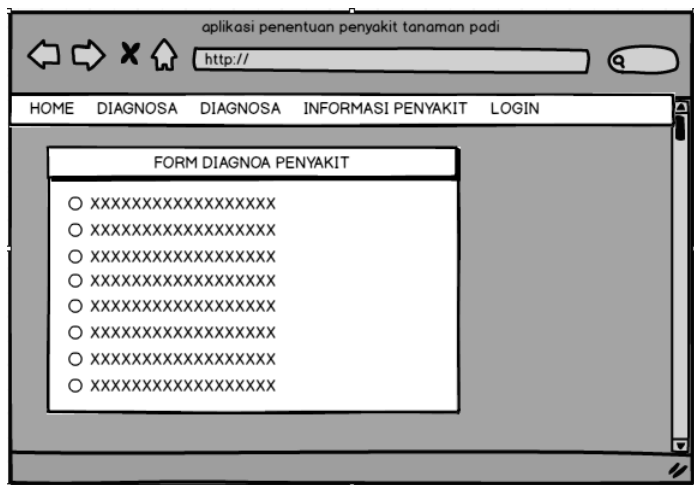

2. Rancangan Masukan Proses Diagnosa Penyakit 
Gambar 9. Halaman Proses Diagnosa Penyakit

3.2.5 Analisis Data

Sebelum melakukan proses penelitian menggunakan metode Fuzzy Mamdani akan dilakukan tahap preprocessing data yang digunakan untuk mengelompokan data secara manual dan juga melakukan penghilangan atribut yang tidak terpakai untuk pemrosesan data. Hasil dari pengolahan data ini yaitu berupa dataset yang dipakai untuk mengolah data menggunakan metode Mamdani.

Berikut adalah table valiabel-variabel yang dapat di gunakan sebagai penilaian.

Jenis penyakit padi beserta kodenya masingmasing dapat dilihat pada tabel berikut ini :

\begin{tabular}{|l|l|}
\hline \multicolumn{1}{|c|}{ ID_Penyakit } & \multicolumn{1}{c|}{ Penyakit } \\
\hline P001 & Blas \\
\hline P002 & Bercar Coklat \\
\hline P003 & Busuk Pipih \\
\hline P004 & Busuk Batang \\
\hline P005 & Tungro \\
\hline P006 & Kerdil Rumput \\
\hline
\end{tabular}

Gejala dari penyakit tanaman padi beserta kodenya masing-masing dapat dilihat pada tabel berikut ini

\begin{tabular}{|l|l|}
\hline \multicolumn{1}{|c|}{ ID_Gejala } & \multicolumn{1}{|c|}{ Gejala } \\
\hline G001 & Berjamur \\
\hline G002 & Lingkungan Berembun \\
\hline G003 & Suhu dingin di siang hari \\
\hline G004 & Hawar pada bibit \\
\hline G005 & Tanah kekurangan harta \\
\hline ID_Gejala & \multicolumn{1}{|c|}{ Gejala } \\
\hline G006 & Kekurangn pengairan \\
\hline G007 & $\begin{array}{l}\text { Jumlah nitroggern tinggi dalam } \\
\text { tanah }\end{array}$ \\
\hline G008 & $\begin{array}{l}\text { Kelembapan relatif tingi dalam } \\
\text { tanah }\end{array}$ \\
\hline G009 & Tanah terlalu rapat \\
\hline G010 & Tanah kering \\
\hline G011 & $\begin{array}{l}\text { Terkubur dalam tanah } \text { yang } \\
\text { lembab dan kedap air }\end{array}$ \\
\hline G012 & Serangan serangga \\
\hline G013 & $\begin{array}{l}\text { Malai yang } \\
\text { penumpukan nirogen }\end{array}$ \\
\hline G014 & Tumbuh kerdil dan \\
\hline G015 & Daun berwarna kuning \\
\hline G016 & Jumlah anakan sedikti \\
\hline G017 & Kerentangan varietas suhu tinggi \\
\hline
\end{tabular}

\begin{tabular}{|l|l|}
\hline G018 & Pertumbuhan padi kerdil \\
\hline G019 & Anakan berlebihan \\
\hline G020 & Tanaman padi tegak lurus \\
\hline G021 & Daun pendek dan sempit \\
\hline G022 & $\begin{array}{l}\text { Banyak daun berwarna hijau } \\
\text { kekuningan }\end{array}$ \\
\hline
\end{tabular}

Definisi Penyakit dan Gejala sebagai berikut :

\begin{tabular}{|c|c|}
\hline Penyakit & Gejala (G) \\
\hline \multirow{3}{*}{$\begin{array}{l}(\mathrm{P} 001) \\
\text { Blass }\end{array}$} & (G001) Berjamur \\
\hline & (G002) Lingkungan Berembun \\
\hline & $\begin{array}{l}\text { (G003) Suhu Dingin di Siang } \\
\text { Hari }\end{array}$ \\
\hline \multirow{3}{*}{$\begin{array}{l}\text { (P002) } \\
\text { Bercak } \\
\text { coklat } \\
\text { (brown } \\
\text { spot) }\end{array}$} & (G004) Hawar Pada Bibit \\
\hline & $\begin{array}{l}\text { (G005) Tanah Kekurangan } \\
\text { Hara }\end{array}$ \\
\hline & (G006) Kurang Pengairan \\
\hline \multirow{3}{*}{$\begin{array}{l}\text { (P003) } \\
\text { Busuk } \\
\text { Pipih }\end{array}$} & $\begin{array}{l}\text { (G007) Jumlah nitroggen } \\
\text { Tinggi Galam Tanah }\end{array}$ \\
\hline & $\begin{array}{l}\text { (G008) Kelembapan relatif } \\
\text { tinggi dalam tanah }\end{array}$ \\
\hline & (G009) Tanaman terlalu rapat \\
\hline \multirow{4}{*}{$\begin{array}{l}\text { (P004) } \\
\text { Busuk } \\
\text { batang } \\
\text { (stemrot) }\end{array}$} & (G010) Tanah kkering \\
\hline & $\begin{array}{l}\text { (G011) Terkubur dalam tanah } \\
\text { yang lembab dan kedap air }\end{array}$ \\
\hline & (G012) Serangan serangga \\
\hline & $\begin{array}{l}\text { (G013) Malai yang basah dan } \\
\text { penumpukan nitrogen }\end{array}$ \\
\hline \multirow{5}{*}{$\begin{array}{l}\text { (P005) } \\
\text { Tungro }\end{array}$} & (G014) Tumbuh kerdil \\
\hline & (G015) Daun berwarna kuning \\
\hline & (G016) Jumlah anakan sedikit \\
\hline & (G017) Kerentangan varietas \\
\hline & Suhu tinggi \\
\hline \multirow{5}{*}{$\begin{array}{l}\text { (P005) } \\
\text { Kerdil } \\
\text { rumput } \\
\text { (grassy } \\
\text { stunt) }\end{array}$} & $\begin{array}{lll}\text { (G018) Pertumbuhan padi } \\
\text { kerdil }\end{array}$ \\
\hline & (G019) Anakan berlebihan \\
\hline & $\begin{array}{l}\text { (G020) Tanaman padi tegak } \\
\text { lurus }\end{array}$ \\
\hline & $\begin{array}{l}\text { (G021) Daun pendek dan } \\
\text { sempit }\end{array}$ \\
\hline & $\begin{array}{l}\text { (G022) Banyak daun berwarna } \\
\text { hijau kekuningan }\end{array}$ \\
\hline
\end{tabular}

Perhitungan secara manual untuk menentukan diagnosa penyakit pada penelitian saat ini penulis menggunakan Fuzzy mamdani dalam metode Max(Maximum) adalah sebagai berikut :

1. Penyakit Blass

IF Berjamur(3)

AND Lingkungan Berembun (1)

AND Suhu Dingin di Disang Hari (5)

THEN Penyakit Blas 


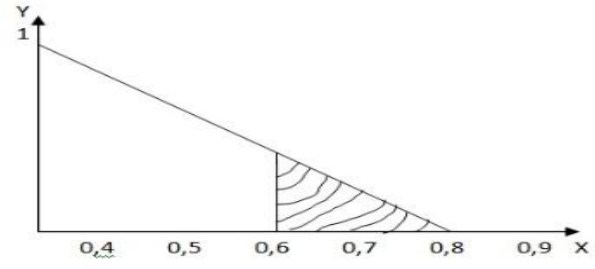

$\mu \mathrm{df}=(3+1+5) / 3=3$

$\mu \mathrm{df}(\mathrm{xi})=\max (\mu \mathrm{df}(\mathrm{xi},) \mu \mathrm{kf}(\mathrm{xi}), \mu \mathrm{kf}(\mathrm{xi}))$

$=\max (3,1,5)$

$=\max (5)$

2. Penyakit Bercak Coklat (Brown Spot)

IF Hawar Pada Bibit (5)

AND Tanah Kekurangan Hara (3)

AND Kurang Pengairan (1)

THEN Bercak Coklat (Brown Spot)

$\mu \mathrm{df}=(4+3+1 / 3=2,6$

$\mu \mathrm{df}(\mathrm{xi})=\max (\mu \mathrm{df}(\mathrm{xi},) \mu \mathrm{kf}(\mathrm{xi}) \mu \mathrm{kf}(\mathrm{xi}))$

$=\max (4,3,1)$

$=\max (4)$

3. Busuk Pipih

IF Jumlah nitroggen Tinggi Galam Tanah (6)

AND Kelembapan Relatif Tinggi Dalam

Tanah (3)

AND Tanaman Terlalu Rapat (1)

THEN Busuk Pipih

$\mu \mathrm{df}=(6+3+1 / 3=3,3$

$\mu \mathrm{df}(\mathrm{xi})=\max (\mu \mathrm{df}(\mathrm{xi},) \mu \mathrm{kf}(\mathrm{xi}) \mu \mathrm{kf}(\mathrm{xi}))$

$=\max (6,3,1)$

$=\max (6)$

4. Busuk Batang (Stemrot)

IF Hawar Pada Bibit (5)

AND Tanah Kekurangan Hara (3)

AND Kurang Pengairan (1)

THEN Bercak Coklat (Brown Spot)

$\mu \mathrm{df}=(5+3+1 / 3=2,6$

$\mu \mathrm{df}(\mathrm{xi})=\max (\mu \mathrm{df}(\mathrm{xi},) \mu \mathrm{kf}(\mathrm{xi}) \mu \mathrm{kf}(\mathrm{xi}))$

$=\max (4,3,1)$

$=\max (4)$

5. Tungro

IF Tumbuh kerdil (5)

AND Daun berwarna kuning (3)

AND Jumlah anakan sedikit (1)

THEN Tungro

$\mu \mathrm{df}=(5+3+1 / 3=3,6$

$\mu \mathrm{df}(\mathrm{xi})=\max (\mu \mathrm{df}(\mathrm{xi},) \mu \mathrm{kf}(\mathrm{xi}) \mu \mathrm{kf}(\mathrm{xi}))$

$=\max (5,3,1)$

$=\max (5)$

6. Kerdil rumput (grassy stunt)

IF Pertumbuhan padi kerdil (5)
AND Anakan berlebihan (3)

AND Tanaman padi tegak lurus (1)

AND Daun pendek dan sempit (1)

THEN Kerdil rumput (grassy stunt)

$\mu \mathrm{df}=(7+3+1 / 3=3,7$

$\mu \mathrm{df}(\mathrm{xi})=\max (\mu \mathrm{df}(\mathrm{xi},) \mu \mathrm{kf}(\mathrm{xi}) \mu \mathrm{kf}(\mathrm{xi}))$

$=\max (4,3,1)$

$=\max (7)$

Adapun logika metode mamdani pada sesi konsultasi sistem, penggunaan konsultasi diberi pilihan jawaban yang masing - masing memiliki bobot sebagai berikut :

Nilai Bobot Fuzzy Mamdani

\begin{tabular}{|c|c|c|}
\hline No & Nilai User & Keterangan \\
\hline 1 & 0 & Tidak ada \\
\hline 2 & 3 & Sedikit \\
\hline 3 & 6 & Sedang \\
\hline 4 & 10 & Banyak \\
\hline
\end{tabular}

\subsection{PEMBAHASAN}

Dari tahapan-tahapan yang telah di lakukan untuk membuat aplikasi penentuan penyakit pada tanaman padi maka dihasilkan program yang kemudian bisa diakses di internet. berikut ini akan dijelaskan berupa form-form dari tampilan program yang telah dibuat

Dari tahapan-tahapan yang telah dilakukan untuk membuat aplikasi penentuan penyakit pada tanaman padi maka dihasilkan program yang kemudian bisa di akses di internet. berikut ini akan dijelaskan berupa form-form dari tampilan program yang telah dibuat :

1. Halaman Utama (Home) User

Pada halaman utama ini berisi informasi mengenai menu-menu yang ada di aplikasi dan user dapat memilih menu sesuai kebutuhan.

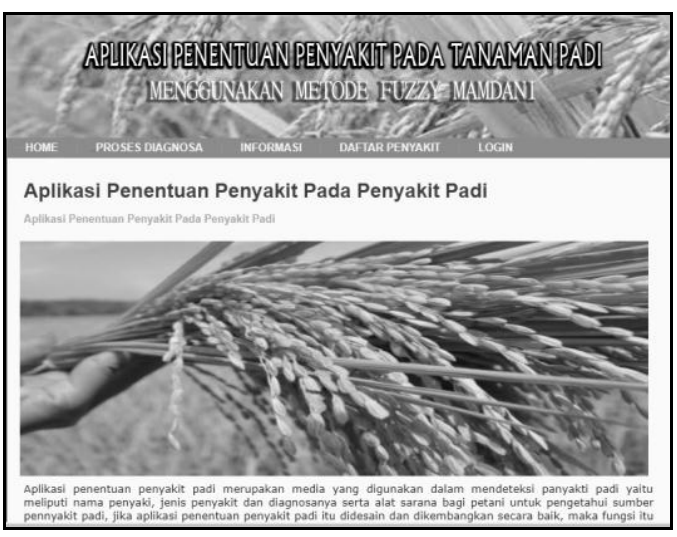


Gambar 10. Halaman Utama (Home) 2. Halaman Input Login Pengguna Halaman ini digunakan untuk login pengguna yang sudah terdaftar. Namun demikian pengguna yang belum terdaftar dapat membuat akun di website pada halaman ini dengan mengklik daftar

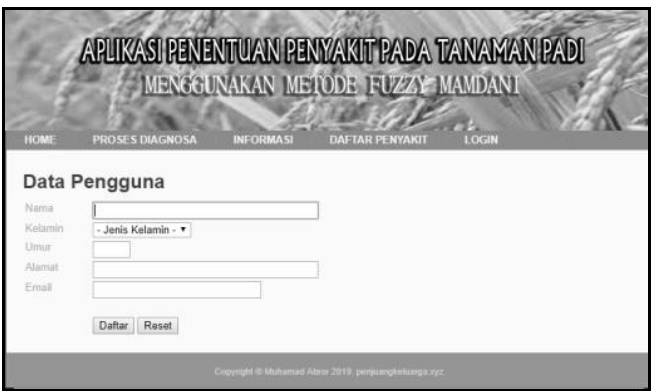

Gambar 11. Halaman Input Login Pengguna

3. Halaman login admin

Halaman ini digunakan hanya untuk login admin, adapun data yang harus di input kan adalah user name dan password,

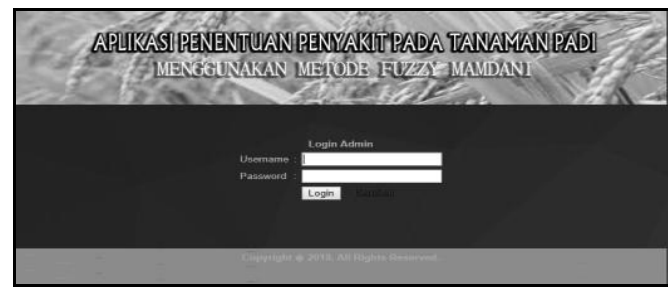

Gambar 12. Halaman Login Admin

4. Halaman Data Input Gejala

Pada halaman ini hanya admin yang dapat menginputkan data-data gejala penyakit tanaman padi, dengan menginputkan kode gejala dan nama gejala.

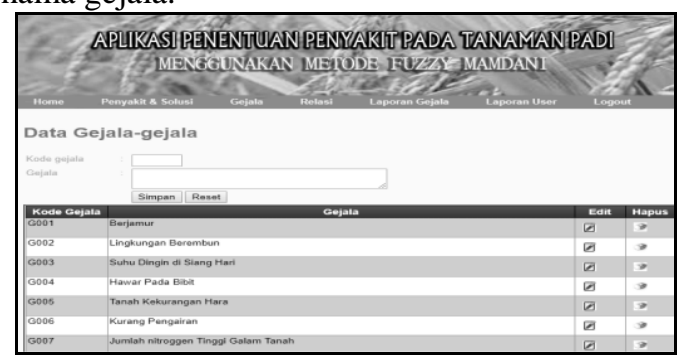

Gambar 13. Halaman Data Input Gejala

5. Halaman Data Input Penyakit

Halaman ini hanya digunakan admin untuk menginputkan data-data jenis penyakit pada penyakit tanaman padi

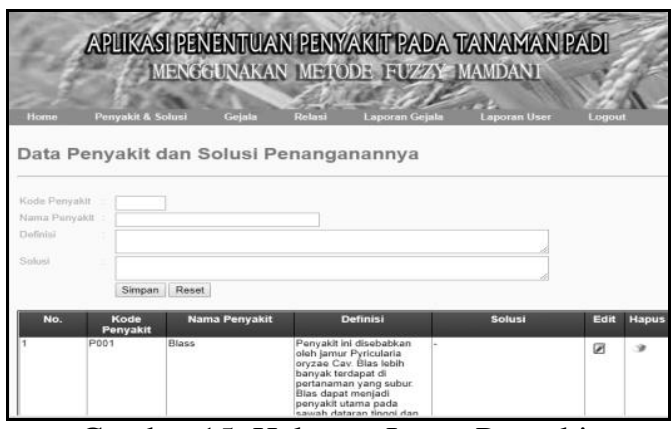

Gambar 15. Halaman Inpun Penyakit

6. Halaman Daftar Penyakit

Pada halaman ini user dapat melihat beberapa macam daftar penyakit tanaman padi

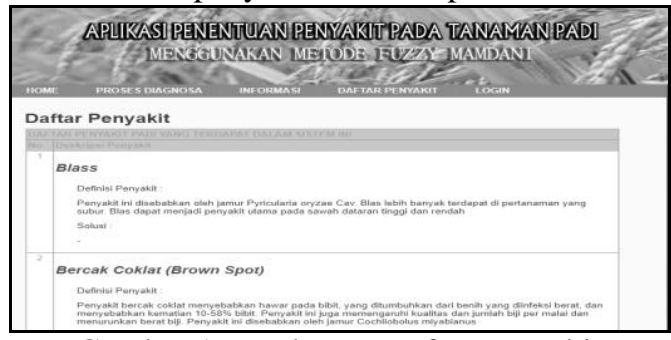

Gambar 16. Halaman Daftar Penyakit

\section{Halaman Daftar User}

Halaman ini berisi data laporan user yang telah login ke aplikasi

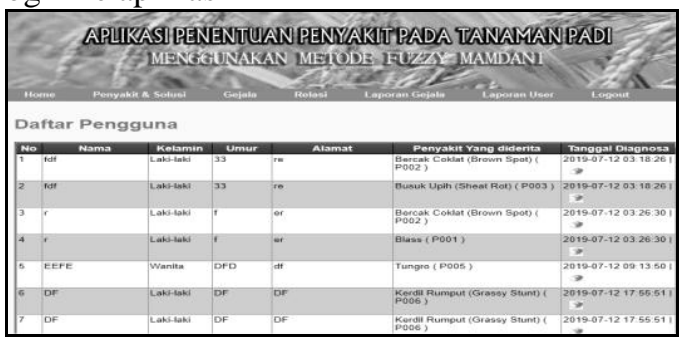

Gambar 17. Halaman Daftar User

8. Halaman Informasi

Halaman ini berisi informasi mengenai penyakit pada tanaman padi

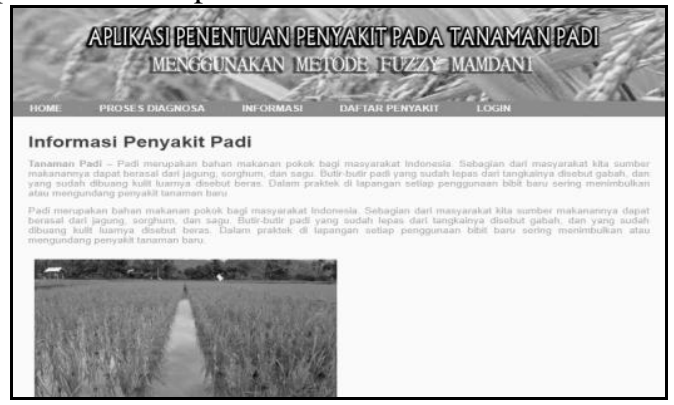

Gambar 18. Halaman Informasi

9. Halaman Form Konsultasi 
Pada halaman user dapat ini dapat memilih beberapa macam gejala penyakit sesuai dengan kiteria penyakit padi.

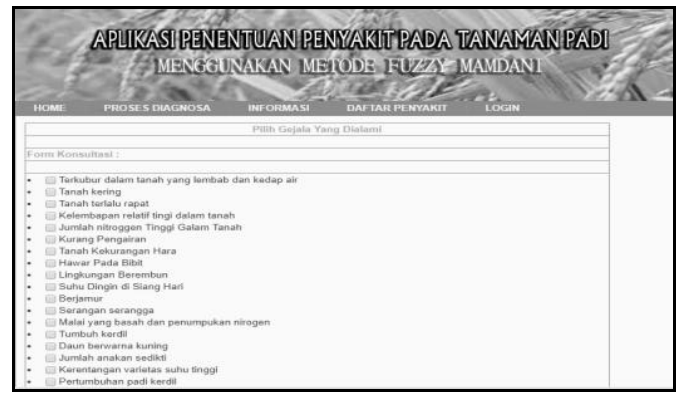

Gambar 19. Halaman Form Konsultasi

10. Halaman Hasil Diagnosa

Halaman ini berisi hasil diagnosa dari apa yang telah diinputkan sebelumnya

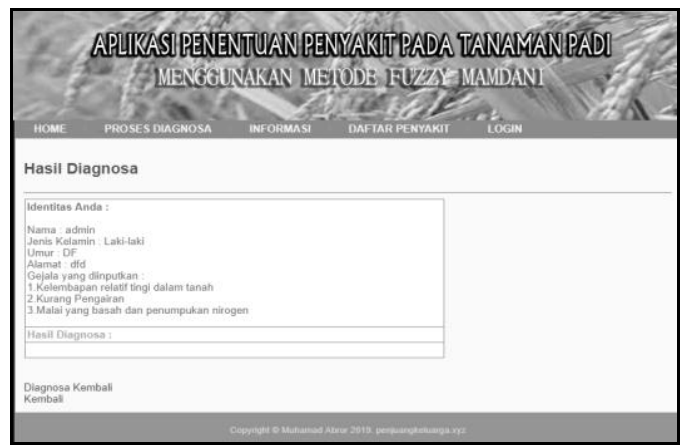

Gambar 20. Halaman Hasil Diagnosa

11. Halaman Halaman logout

Pada halaman ini admin dapat keluar dari halalam dashboard administrator. Dan kembali ke halaman utama

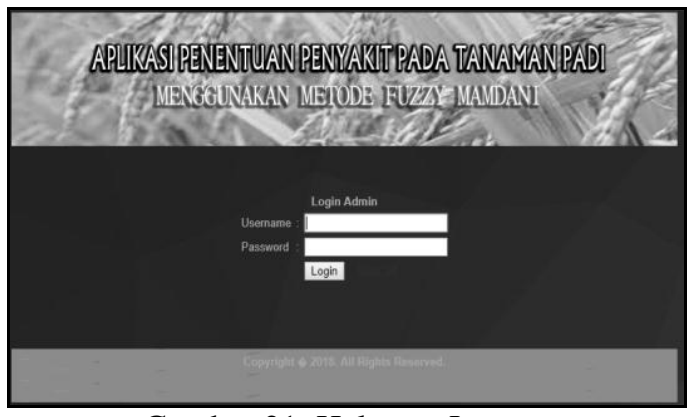

Gambar 21. Halaman Logout

\section{PENUTUP}

Berdasarkan hasil penelitian yang dilakukan, maka kesimpulan dalam penelitian adalah sebagai berikut:

1. Aplikasi yang dihasilkan memudahkan pengguna untuk mengetahui informasi penyakit padi secara online, memberikan informasi yang cepat mengenai info penyakit dan solusinya serta informasi yang tersedia pada aplikasi ini yang bermanfaat bagi pengguna.

2. Dengan menggunakan metodologi fuzzy mamdani, penulis dapat mengatasi permasalahan yang terjadi selama pengembangan.

3. Dengan menggunakan Unified Modeling Language dapat mengakomodasi perubahan kebutuhan perangkat lunak dapat teratasi dan kesalahan yang terjadi seperti error atau bug dapat ditemukan dan diperbaiki selama tahapan pengembangan.

4. Para pakar petani perlu melakukan sosialisasi kepada pengguna dengan tersedianya aplikasi penentuan penyakit pada tanaman padi.

5. DAFTAR PUSTAKA

[1] Arief M Rudianto, 2011, Pemrograman Web Dinamis menggunakan PHP dan MySQL. C.V ANDI OFFSET. Yogyakarta

[2] Mulhim, Imam. 2013. Aplikasi Informasi dengan PHP \& MySQL. Maxikom. Palembang

[3] Moh. Nazir, 2014. Metodologi Penelitian, Ghalia Indonesia, Bogor

[4] Rosa dan Shalahuddin, 2014, Rekayasa Perangkat Lunak Struktur dan Berorientasi Objek. Bandung : Informatika.

[5] Sibero, Alexander F.K. 2012. Kitab Suci Web Programing. Jakarta: Mediakom 